\title{
Potential therapeutic effect of Allium cepa L. and quercetin in a murine model of Blomia tropicalis induced asthma
}

\author{
Tatiane Teixeira Oliveira ${ }^{1}$, Keina Maciele Campos ${ }^{1}$, Ana Tereza Cerqueira-Lima', Tamires Cana Brasil Carneiro ${ }^{1}$, \\ Eudes da Silva Velozo², Ingrid Christie Alexandrino Ribeiro Melo ${ }^{3}$, Eugênia Abrantes Figueiredo ${ }^{3}$, \\ Eduardo de Jesus Oliveira ${ }^{3}$, Darizy Flávia Silva Amorim de Vasconcelos ${ }^{1}$, Lain Carlos Pontes-de-Carvalho ${ }^{4}$, \\ Neuza Maria Alcântara-Neves ${ }^{1}$ and Camila Alexandrina Figueiredo ${ }^{1 *}$
}

\begin{abstract}
Background: Asthma is an inflammatory condition characterized by airway hyperresponsiveness and chronic inflammation. The resolution of inflammation is an essential process to treat this condition. In this study we investigated the effect of Allium cepa L. extract (AcE) and quercetin (Qt) on cytokine and on smooth muscle contraction in vitro and its therapeutic potential in a murine model of asthma.

Methods: AcE was obtained by maceration of Allium cepa L. and it was standardized in terms of quercetin concentration using high performance liquid chromatography (HPLC). In vitro, using AcE 10, 100 or $1000 \mu \mathrm{g} / \mathrm{ml}$ or Qt 3.5, 7.5, $15 \mu \mathrm{g} / \mathrm{ml}$, we measured the concentration of cytokines in spleen cell culture supernatants, and the ability to relax tracheal smooth muscle from A/J mice. In vivo, Blomia tropicalis (BT)-sensitized A/J mice were treated with AcE 100, $1000 \mathrm{mg} / \mathrm{kg}$ or $30 \mathrm{mg} / \mathrm{kg}$ Qt. We measured cell influx in bronchoalveolar lavage (BAL), eosinophil peroxidase (EPO) in lungs, serum levels of Bt-specific lgE, cytokines levels in BAL, and lung histology.
\end{abstract}

Results: We observed a reduction in the production of inflammatory cytokines, a relaxation of tracheal rings, and a reduction in total number of cells in BAL and EPO in lungs by treatment with AcE or Qt.

Conclusion: AcE and Qt have potential as antiasthmatic drugs, as they possess both immunomodulatory and bronchodilatory properties.

Keywords: Natural product, Asthma, Blomia tropicalis, Allium cepa L., Quercetin

\section{Background}

Asthma is an inflammatory condition characterized by airway hyperresponsiveness, mucus cell hyperplasia, inflammatory cell infiltration and reversible bronchoconstriction, which may progress to airway remodeling with fibrosis and an increase in smooth muscle reactivity [1-4]. In allergic asthma, exposure to allergens causes an imbalance between the T helper type (Th) 1 and Th2 responses. Cytokines produced by the Th2-type CD4+ T cells (interleukin (IL-4, IL-5, IL-13) in asthma have a central role in orchestrating the inflammatory response.

\footnotetext{
* Correspondence: cavfigueiredo@gmail.com

${ }^{1}$ Instituto de Ciências da Saúde, Universidade Federal da Bahia, Salvador, Bahia, Brazil

Full list of author information is available at the end of the article
}

Strong support for this T-cell-centric paradigm has been enriched by the identification of Treg cells with the capacity to control both Th1 and Th2 responses [5]. The synthesis and release of IL-4 (which stimulates B cells to synthesize IgE), IL-13 (which stimulates mucus production) and IL-5 (which is necessary for eosinophilic infiltration to the lung tissue) increase vascular permeability and chemotaxis, which amplify the inflammatory response. Additionally, activated mast cells are able during an allergen challenge to release several inflammatory and bronchoconstrictor mediators [6,7].

The prevalence of asthma continues to rise worldwide [8], and treatment of asthma faces many challenges, including under diagnosis, access to care, ability of healthcare workers to manage asthma, education of healthcare 
providers and patients, and availability and affordability of inhaled therapy [9]. Treatment with inhaled steroids and bronchodilators often results in good control of symptoms [10]. However, the treatment for patients with severe asthma with uncontrolled and frequent exacerbations still contributes to morbidity and mortality of asthma in all age groups and remains a challenge $[11,12]$. The safety concerns and the obstacles for the asthmatic patients justify continued efforts to find new alternative therapies [13].

Historically, herbal medicine has been studied in asthma treatment, and some of the drugs currently used to treat this disease such as the inhaled corticosteroids, sympathomimetics, anti-cholinergics, methylxanthines and cromones have origins in herbal treatments [14]. Thus, our group performed an ethnopharmacological survey [15], and one of the herbs described was Allium cepa L., commonly used to treat inflammatory conditions such as asthma [16,17].

Several plant-derived secondary metabolites have been shown to interfere directly with molecules and mechanisms, such as the mediation of inflammatory responses and activity of second messengers, as well as the expression of transcription factors and key pro-inflammatory molecules [18]. The main compounds found in Allium cepa L. extract (AcE) are the flavonoids such as quercetin, which are natural phenolic compounds present in fruits and vegetables, exhibiting many pharmacological properties such as its anti-inflammatory and antioxidant effects [17,19-21]. Along with flavanols, the major bioactive constituents in Allium cepa L. are sulfurous compounds. In previous studies, using mass spectrometry for direct analysis of volatile sulfurous compounds has described the presence of propanethiol, dipropyl disulfide and thiosulfinates [22-24]. The sulfoxides, which are responsible for the onion flavor and odor, might also be responsible in part for the onion biological activity of different Allium spp. species. The propanethiol is suggested to be the main source of the characteristic onion odor [23,24].

In previous studies, the anti-allergic potential of the extracts of Allium cepa L. [16,17] and its flavonoid quercetin $[18,19,25]$ has been reported using a mouse model of ovalbumin (OVA)-induced asthma. This study is the first which was conducted using extracts of Allium cepa L. (AcE) and quercetin treatment in murine model of allergic airway disease induced by the sensitization to the clinically relevant aeroallergen Blomia tropicalis mite. This mite is a major house dust mite in dust worldwide [26]. In addition, it has been shown that flavonoids, typically found in Allium cepa, have a relaxing effect on the smooth muscle of isolated trachea and may have bronchodilator effect $[25,27,28]$.

Thus, the objective of this study was to assess the therapeutic potential (anti-inflammatory and bronchodilator) of the methanolic extract of Allium cepa L. (AcE) and its flavonoid quercetin $(\mathrm{Qt})$ in a murine model of respiratory allergy to Blomia tropicalis mite.

\section{Methods \\ Animals}

A/J mice aged 5-7 weeks (20-25 g), females, were from the Fundação Oswaldo Cruz, Bahia, Brazil. Five animals per group were used in each experiment. Mice were housed in controlled temperature and humidity environment with 12-hour light-dark cycles, and had free access to food and water. The experimental procedures were approved by the Ethical Committee for Use of Experimental Animals of the Faculdade de Odontologia, Universidade Federal da Bahia, Brazil (protocol number: 02/09).

\section{Sensitization and challenge of mice with Blomia tropicalis (Bt-sensitized mice)}

A B. tropicalis extract was obtained as previously described [15]. The experimental model of allergy to B. tropicalis (Bt) dust mite was used as previously described [29]. The animals were sensitized with subcutaneous injections of $\mathrm{Bt}$ (100 $\mu \mathrm{g}$ of protein) adsorbed to $4 \mathrm{mg} / \mathrm{ml}$ of $\mathrm{Al}(\mathrm{OH})_{3}$ in saline on days 0 and 7 , and 1 day after the last sensitization the animals received four intranasal challenges with Bt (10 $\mu \mathrm{g} /$ instilation) every other day. Animals were euthanized with intraperitoneal injections of xilazine and ketamine (40 mg/kg/body weight), 24 hours after the last challenge. A schematic diagram of the sensitization and allergen challenge schedule is shown in Figure 1.

\section{Preparation of the Allium cepa L. extract and obtaining of quercetin}

A methanolic extract was obtained by maceration of Allium cepa L. previously peeled and cut in a closed container containing $1000 \mathrm{ml}$ of $99.8 \%$ methyl alcohol $\left(\mathrm{CH}_{3} \mathrm{OH}\right)$ during 7 days at room temperature. Subsequently, we proceeded to filtration of the extractive liquid, which then was rota-evaporated at a temperature of $60-70^{\circ} \mathrm{C}$ in a thermostatic bath. This concentration process was repeated three times. The AcE was dried in the oven and then maintained at $-20^{\circ} \mathrm{C}$ until use.

The flavonoid quercetin [2-(3, 4-dihydroxyphenyl)-3, 5, 7-trihydroxy-4H-1-benzopyran-4-one, 3, 3', 4', 5, 6 entahydroxyflavone] was obtained commercially $(98 \%$ purity) from Sigma-Aldrich ${ }^{\circ}$ (St. Louis, MA, USA).

In vitro, different concentrations of AcE- $10 \mu \mathrm{g} / \mathrm{ml}$ $\left(\mathrm{AcE}_{10}\right), 100 \mu \mathrm{g} / \mathrm{ml}\left(\mathrm{AcE}_{100}\right)$, or $1000 \mu \mathrm{g} / \mathrm{ml}\left(\mathrm{AcE}_{1000}\right)$, and $\mathrm{Qt}-3.5 \mu \mathrm{g} / \mathrm{ml}\left(\mathrm{Qt}_{3.5}\right), 7.5 \mu \mathrm{g} / \mathrm{ml}\left(\mathrm{Qt}_{7.5}\right)$ or $15 \mu \mathrm{g} / \mathrm{ml}$ $\left(\mathrm{Qt}_{15}\right)$ were tested. In vivo, the tested groups were animals sensitized to $\mathrm{Bt}$ and daily treated orally with AcE containing $100 \mathrm{mg} / \mathrm{kg}\left(\mathrm{AcE}_{100}\right)$ and $1000 \mathrm{mg} / \mathrm{kg}$ $\left(\mathrm{AcE}_{1000}\right)$ or $30 \mathrm{mg} / \mathrm{kg} \mathrm{Qt}\left(\mathrm{Qt}_{30}\right)$ dissolved in saline (vehicle) from the 8 th to the 14th day of the experimental 


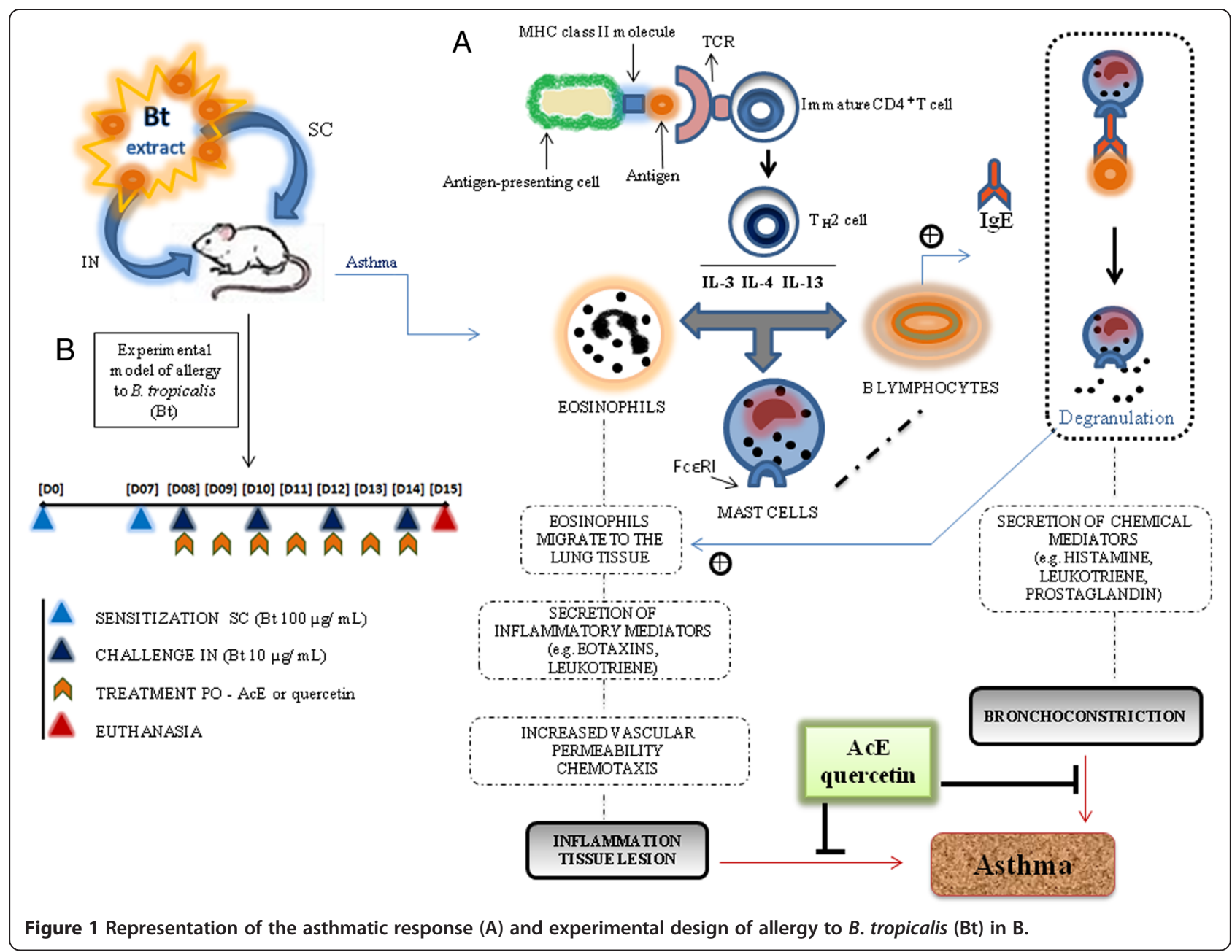

protocol and one hour after the intranasal challenges with Bt. Mice receiving the following treatments were studied: non-sensitized and vehicle-treated mice (negative control group); Bt, Bt-sensitized mice and vehicle-treated mice (positive control group); $\mathrm{Bt} / \mathrm{AcE}_{100}, \mathrm{Bt}$-sensitized and $\mathrm{AcE}_{100}$-treated mice; $\mathrm{Bt} / \mathrm{AcE}_{1000}$, Bt-sensitized and $\mathrm{AcE}_{1000^{-}}$treated mice; Bt/Qt, Bt-sensitized and $\mathrm{Qt}_{30^{-}}$ treated mice (tested groups).

\section{Standardization of Allium cepa L. extract}

The major flavonoid found in Allium cepa L. is quercetin $[30,31]$. The AcE was standardized in terms of quercetin concentration by high performance liquid chromatography, with ultraviolet light detection at $250 \mathrm{~nm}$, using a C-18 column $(150 \times 4.6 \mathrm{~mm}$ ID, $5 \mu \mathrm{m}$ particle size, Thermo Scientific) and a C-18 pre-column (Phenomenex, Torrance, USA). The mobile phase consisted of $0.1 \%$ aqueous formic acid (A) and methanol (B) at a flow rate of $1.0 \mathrm{ml} / \mathrm{min}$. The following gradient elution method was used for separation: $5 \%$ to $90 \%$ of B in A in 30 min. The injection volume was $20 \mu \mathrm{L}$ and quercetin calibration curves were in the range of 5 to $100 \mu \mathrm{g} / \mathrm{ml}$.

\section{Cell viability assay}

Cell viability after in vitro exposure to AcE and Qt was determined using the MTT assay. Spleen cells were seeded at a density of $5 \times 10^{5}$ cells/well in 96-well plate and were then exposed to AcE and Qt diluted in RPMI. After 48 hours of incubation, the viability of the cells was evaluated by using FCS-free medium containing $1 \mathrm{mg} / \mathrm{ml}$ of 3-[4, 5-dimethylthiazol-2-yl]-2, 5 diphenyltetrazoliumbromide (MTT, Sigma). After 4 hours of incubation at $37^{\circ} \mathrm{C}$, the medium was discarded and the formazan blue dissolved with DMSO. The optical density (OD) was measured at $540 \mathrm{~nm}$. The percentage of viable cells was calculated by defining the cell viability without treatment as $100 \%$.

\section{In vitro cytokine production by spleen cells}

Levels of IL-4, IL-5 and IL-13 T-helper (Th) type 2 cytokines in splenocytes cultures were evaluated. According to the method described by Bezerra-Santos [32], splenocytes from Bt-sensitized mice were washed twice in RPMI medium by centrifugation at $200 \times \mathrm{g}$ for $10 \mathrm{~min}$. The obtained pellet was resuspended in RPMI medium 
supplemented with $200 \mathrm{mM}$ l-glutamine, 100 units $/ \mathrm{ml}$ penicillin, $100 \mu \mathrm{g} / \mathrm{ml}$ streptomycin, $5 \beta$-mercaptoethanol and $10 \%$ fetal calf serum (Gibco, Pisley, UK). Viable cells number was determined in a hemocytometer by exclusion using trypan blue. The spleen cells were plated in 96-well flat-bottomed tissue culture plates (Costar, Cambridge, MA, USA) at a density of $5 \times 10^{5}$ cells/well. The cells were treated with non-cytotoxic concentrations of AcE or Qt and stimulated with $5 \mu \mathrm{g} / \mathrm{ml}$ of pokeweed (PWM) (Sigma Aldrich, Saint Louis, MA, USA). The cells were incubated at $37^{\circ} \mathrm{C}$ in a humidified atmosphere of $5 \% \mathrm{CO}_{2}$ for 48 hours. Supernatants of the cell cultures were collected and analyzed by enzyme-linked immunosorbent assay (ELISA) for IL-4, IL-5 and IL-13 cytokine concentrations (BD Pharmingen, San Diego, CA, USA).

\section{In vitro airway smooth muscle relaxation}

AJ mice were euthanized and the trachea was rapidly removed. The trachea was cleared of loose connective tissue and divided into 2 rings of $2 \mathrm{~mm}$, containing on average three to four cartilage bands. The rings were suspended on metal rods, attached to a force transducer (FORT10 WPI, Sarasota, USA) and placed in tanks for isolated organ with Krebs-bicarbonate solution (composition in $\mathrm{mM}: \mathrm{NaCl} 119, \mathrm{NaHCO}_{3} 25, \mathrm{CaCl}_{2} \times \mathrm{H}_{2} \mathrm{O}$ 1.6, $\mathrm{KCl} 4.7, \mathrm{KH}_{2} \mathrm{PO}_{4} 1.2, \mathrm{MgSO}_{4} \times 7 \mathrm{H}_{2} \mathrm{O} 1.2$ and glucose $11.1)$, aerated with a carbogen mixture $\left(95 \% \mathrm{O}_{2}\right.$ and $5 \%$ $\mathrm{CO}_{2}$ ) and maintained at $37^{\circ} \mathrm{C}$. After the stabilization period (1 hour at $0.5 \mathrm{~g}$ ), the rings were contracted with $10 \mu \mathrm{M}$ of carbachol (Cch; Sigma, St Louis, MA, USA) to assess the contractile state of the tissue and to evaluate the presence of functional epithelium. The rings, after reaching a plateau of contractile state, were stimulated with bradykinin (Bk; Sigma, St Louis, MA, USA) $\left(10^{-6} \mathrm{M}\right)$. The rings were again contracted with Cch $(10 \mu \mathrm{M})$ and cumulatively increasing concentrations of AcE or Qt were added. Concentration response curve was constructed and data were analyzed. Additionally, the tracheal rings were previously exposed to IL-13 in culture as described previously [33] to evaluate the effects of AcE or Qt on the hyper-responsive airway smooth muscle. The rings were placed individually in each well of a 48 -well plate and incubated at $37^{\circ} \mathrm{C}$ in the presence or absence of IL-13 (10 ng/ml, 24 hours; BD Pharmingen, San Diego, CA, USA) in supplemented Dulbecco's modified Eagle's medium (containing $25 \mathrm{mM}$ D-glucose, $1 \mathrm{mM}$ sodium pyruvate, $100 \mathrm{U} / \mathrm{ml}$ penicillin, $100 \mu \mathrm{g} / \mathrm{ml}$ streptomycin, $0.2 \mathrm{M} \mathrm{L}$-glutamine, $2.5 \mu \mathrm{g} / \mathrm{ml}$ Fungizone, and $0.1 \% \mathrm{w} / \mathrm{v}$ bovine serum albumin) (Sigma, St Louis, MA, USA) for 24 hours. Cumulative concentrationresponse curves to $\mathrm{Cch}$ after incubation in the absence or presence of IL-13 was built to analyze the hyper-reactivity of smooth muscle. After that, concentration-response curved for AcE or Qt was built.

\section{Collection of bronchoalveolar lavage (BAL) fluid and cell counting}

The trachea of the euthanized mice were canulated and BAL fluid was obtained by three successive aspirations (total volume $1.5 \mathrm{ml}$ ) via tracheal cannulation of phosphate buffered saline, $\mathrm{pH}$ 7.4 (PBS) containing $1 \%$ of bovine serum albumin (Sigma-Aldrich St. Louis, MA, USA). Total number of leukocytes in the BAL was determined using Trypan blue and differential cell counts for eosinophils were performed by using Wright-stained cytospin preparations. Differential counts of eosinophils of at least 100 cells were made in a blind fashion in accordance with standard morphologic protocol. The concentrations of IL-4, IL-5 and IL-13 in BAL were quantified by ELISA, as recommended by the manufacturer (BD Pharmingen, San Diego, CA, USA).

\section{Eosinophil peroxidase (EPO) activity in lung}

The cell suspensions from mouse lungs were frozen and thawed three times in liquid nitrogen. After centrifugation at $4^{\circ} \mathrm{C}$ for $10 \mathrm{~min}$ at $1000 \mathrm{~g}$, the cell lysates were placed into wells of 96-well plates, followed by the addition of the chromogen and substrate solution $(1.5 \mathrm{mmol} / \mathrm{L}$ of o-phenylenediamine and $6.6 \mathrm{mmol} / \mathrm{L}$ of $\mathrm{H}_{2} \mathrm{O}_{2}$ in $0.05 \mathrm{~mol} / \mathrm{L}$ Tris- $\mathrm{HCl}$, pH 8.0). After 30 minutes room temperature, the reaction was stopped with the addition of $0.2 \mathrm{~mol} / \mathrm{L}$ citric acid, and the absorbance of the sample determined at $492 \mathrm{~nm}$ in an ELISA reader.

\section{Measurement of serum levels of Bt-specific lgE}

Anti-Bt IgE antibody levels from mice were determined by indirect ELISA. 96-well micro titer high-binding plate (Costar, Cambridge, MA, USA) were coated with Bt (100 $\mu \mathrm{g} /$ well) overnight (at $4^{\circ} \mathrm{C}$ ). The serum samples were added and the plates were incubated again. Biotin-conjugated IgE anti-mouse (BD Pharmingen, San Diego, CA, USA) were added to the wells and incubated during 1 hour at room temperature (RT). A solution of avidin-horseradish peroxidase (BD Pharmingen, San Diego, CA, USA) was then added to each well for 30 minutes. After that, a solution containing 3, 3', 5, 5'-tetramethylbenzidine and hydrogen peroxide (BD Pharmingen, San Diego, CA, USA) was added and incubated during additional 30 minutes (at RT). The reaction was stopped with $4 \mathrm{M}$ sulfuric acid. Between all steps the wells were washed 3 times with PBS containing $0.05 \%$ Tween 20 (PBS-T). The absorbance of each sample was determined at $492 \mathrm{~nm}$ in an ELISA reader.

\section{Lung histology}

The analyses the histopathological changes and the degree of inflammation in peribronchiolar and perivascular regions were performed. The lungs were perfused, via the heart right ventricle, to remove residual blood, and immersed in 10\% (v/v) formaldehyde (Sigma-Aldrich St. Louis, MA, USA). The tissue was dehydrated, embedded 
in paraffin and cut in $5 \mu \mathrm{m}$ sections. The slides were stained with hematoxylin-eosin (HE) for inflammatory cell infiltration and were then stained with periodic acidSchiff (PAS) for the evaluation of mucus production, under light microscopy with $40 \times$ magnification.

\section{Statistical analysis}

Multiple comparisons were performed by one-way analysis of variance (ANOVA) and Tukey's post-test (for data with normal distribution). Data were expressed as mean \pm standard error of the mean. Differences in $p$ values $\leq 0.05$ were considered statistically significant. Each experiment was repeated at least twice.

\section{Results}

Quercetin is present in the methanolic extract of Allium cepa $\mathrm{L}$ The chromatogram of the methanolic extract of AcE (Figure 2A) and a quercetin standard solution (Figure 2B) demonstrated the separation of a compound in the methanolic extract with the same retention time of $\mathrm{Qt}$ in the standard sample (Figure 2A and $\mathrm{B}$ ). The calculated average percentage of $\mathrm{Qt}$ in the AcE extract is 2.5\% (based on peak area).

\section{Effect of AcE and Qt on cell viability and cytokine levels in spleen cells culture}

The non-cytotoxic concentrations of $\mathrm{AcE}$ and Qt used were determined by MTT assay. As can be seen in Figure 3A, none of the evaluated concentrations were toxic for spleen cells (AcE: $1000-10 \mu \mathrm{g} / \mathrm{ml}$ and Qt: $15-3.75 \mu \mathrm{g} / \mathrm{ml}$ ). The production of Th2 cytokines, including IL-4, IL-5, and IL13 by PWM-stimulated splenocytes from Bt-sensitized mice was increased in comparison to that by PWM-nonstimulated splenocytes from Bt-sensitized mice $(\mathrm{p}<0.001)$. IL-4 (Figure 3B), IL-5 (Figure 3C), and IL-13 (Figure 3D) levels were significantly lower in the culture supernatants
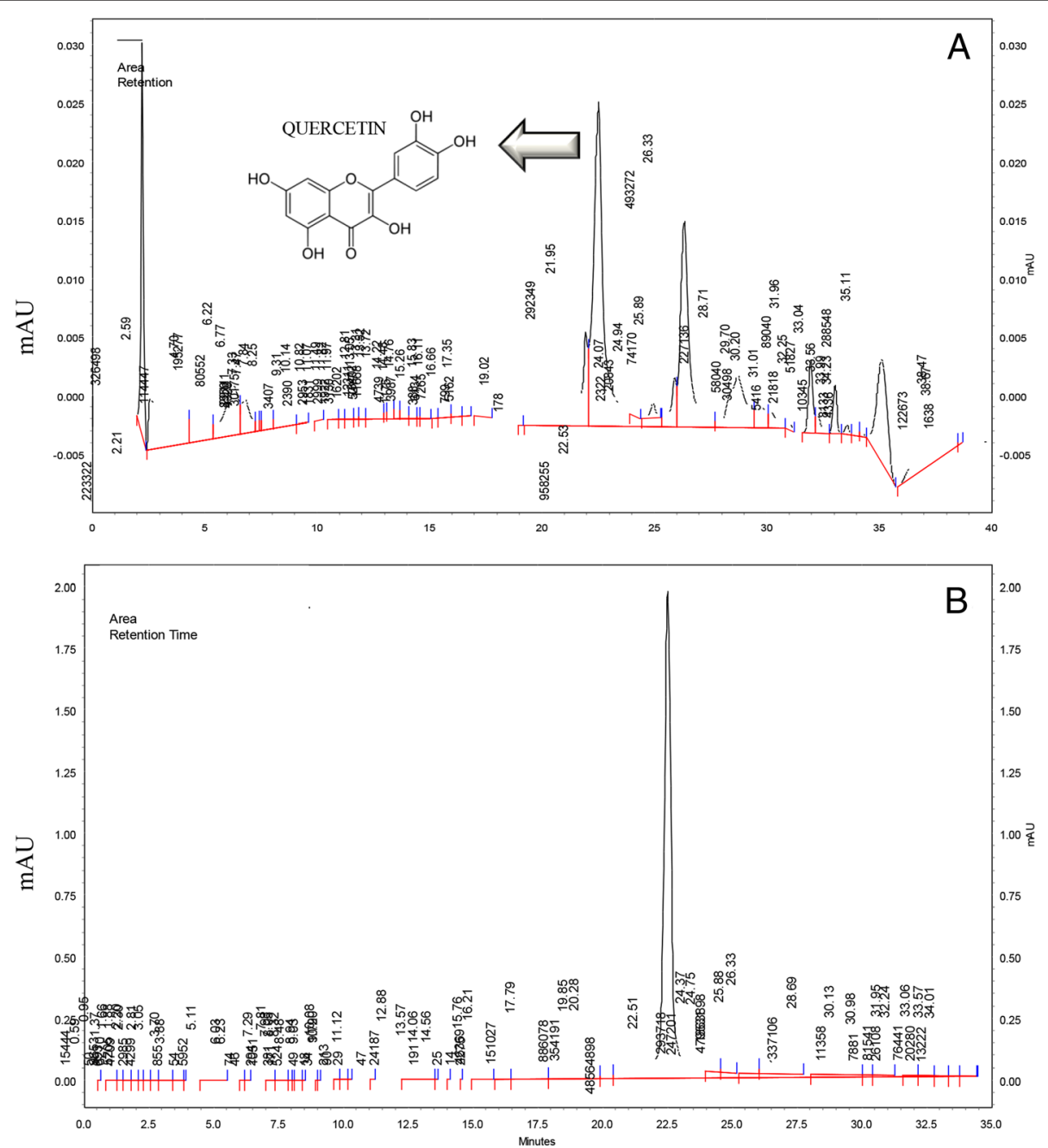

Figure 2 Chromatogram of samples subjected to high performance liquid chromatography. (A) Chromatogram of Allium cepa L. methanol extract. (B) Chromatogram of quercetin. Retention times of 22.51 minutes are shown above peaks in (A) and (B). 


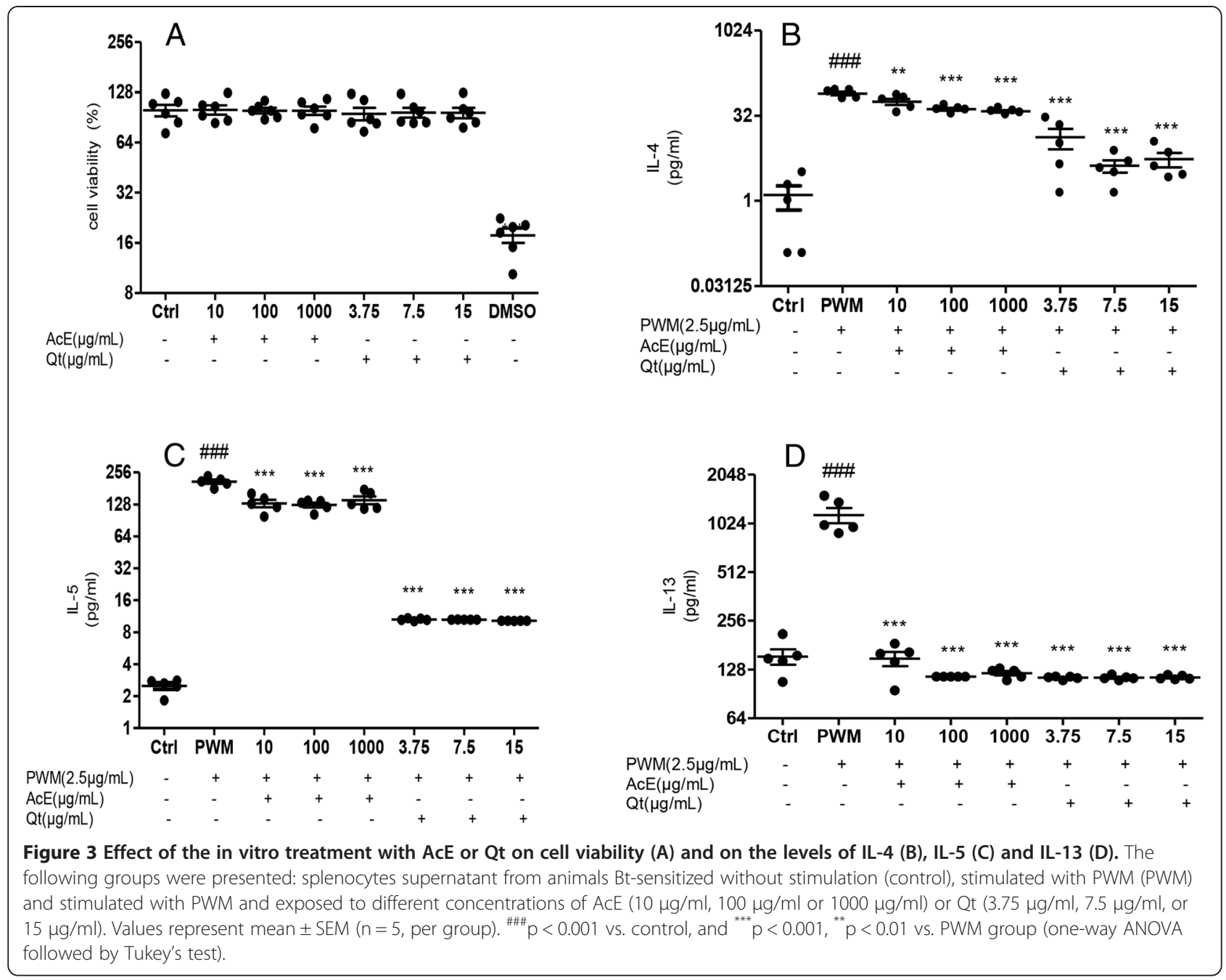

of splenocytes from PWM-stimulated mice that had been treated with AcE or Qt, when compared to the control group.

\section{Effect of AcE and Qt on airway smooth muscle contractility}

As can be seen in Figure 4(A and C), the cumulative addition of AcE $\left(1,3,10,30,10^{2}\right.$, and $\left.3 \times 10^{2} \mu \mathrm{g} / \mathrm{ml}\right)$ and Qt $\left(10^{-8}, 10^{-7}, 10^{-6}, 10^{-5}, 10^{-4}\right.$, and $\left.10^{-3} \mathrm{M}\right)$, respectively, induced a transient relaxing effect, in a concentrationdependent manner, with the values of CE50 $=7.1(1.8-$ 27.4) $\mathrm{mg} / \mathrm{ml}$ and CE50 $=8.9(4.8-16.2) \times 10^{-5} \mathrm{M}$ for AcE and Qt, respectively. The data set may be seen in Figure 4 (B and D), which shows an ACE concentration-response curve. The percentage of the maximum relaxation (Emax) induced by AcE was Emax $=47.2 \pm 7.0$ (\%), and induced by Qt was Emax $=84.0 \pm 13.1$ (\%).

Additionally, in our in vitro model of hyper-reactivity using IL-13, murine tracheal rings that were incubated overnight with IL-13 $(10 \mathrm{ng} / \mathrm{ml})$ increased the constrictor responses to Cch but without changes in pharmacological potency $(E \max =0.84 \pm 0.08(\%) ; \mathrm{pD} 2=6.8 \pm 0.1091)$ when compared with non-treated rings Emax $=0.55 \pm 0.04$ (\%); $\mathrm{pD} 2=6.4 \pm 0.1887$ (Figure 4E). Moreover, a reduction in intensity of smooth muscle contraction in the absence or presence of IL-13 with different concentrations of AcE $(\mathrm{CE} 50=0.075(0.011-0.5) \quad \mathrm{Emax}=25.14 \pm 5.52(\%))$ or Qt $(\mathrm{pD} 2=4.6 \pm 0.07$ Emax $=104.42 \pm 2.94$ (\%) was observed (Figure 4F and G). However, the efficacy and potency of the tested drugs in hyper-reactive tracheal rings (sensitized with IL-13) were not altered when the drugs were tested in normal rings, not sensitized with IL-13.

\section{Effect of AcE or Qt on cell influx in BAL fluid and on EPO levels in lungs}

We examined changes in total cell numbers in the BAL fluid to determine the effects of AcE or Qt on experimental respiratory allergy. The BAL cellularity was estimated by counting the cells recruited to the BAL fluid $48 \mathrm{~h}$ after the last challenge. In relation to the control group, Bt-sensitized mice displayed a significant increase in total cell numbers $(\mathrm{p}<0.01)$. However, in Bt-sensitized mice, the 


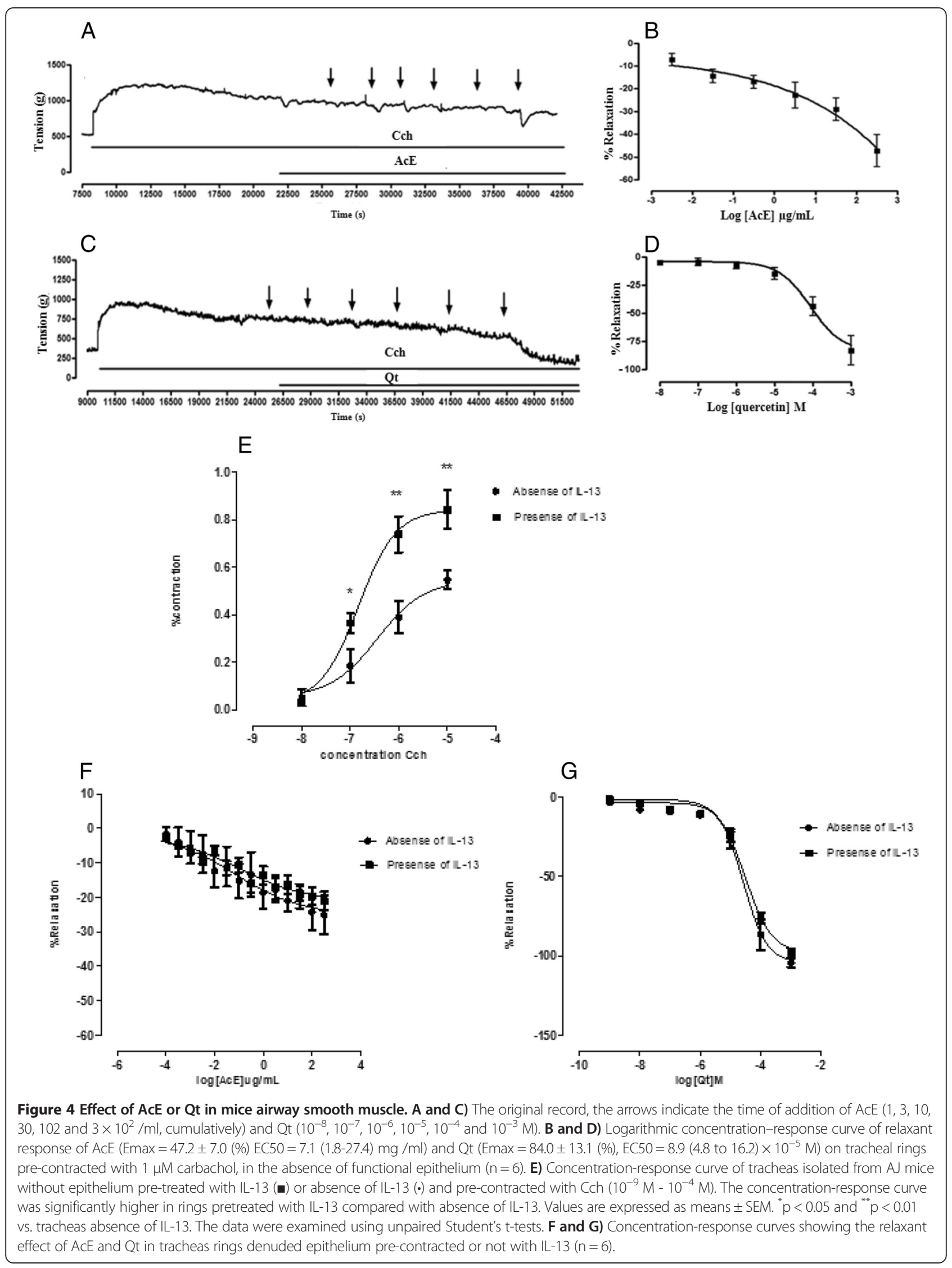


treatment with $\mathrm{AcE}_{100}(\mathrm{p}<0.05), \mathrm{AcE}_{1000}(\mathrm{p}<0.01)$ or $\mathrm{Qt}_{30}$ $(\mathrm{p}<0.05)$ decreased the total number of cells in relation to untreated Bt-sensitized mice (Figure 5A). Additionally, the lung tissue was collected 48 hours after the final Bt challenge and EPO activity were measured. The EPO levels from lung tissue of Bt-sensitized mice were increased in relation to control group $(p<0.001)$. The mice from Bt-sensitized group and treated with $\mathrm{AcE}_{100}(\mathrm{p}<0.001)$ or $\mathrm{AcE}_{1000}(\mathrm{p}<0.001)$ had significantly lower EPO levels after respiratory allergy induction. No effect in EPO levels was observed in mice treated with $\mathrm{Qt}_{30}$ (Figure 5B).

\section{Effect of treatment with AcE or Qt on inflammatory cell infiltration and amount of mucus in lungs}

Because AcE or Qt inhibits inflammatory cell recruitment into the lung tissue and EPO levels in lungs, we examined the histology of lung tissue. In Bt-induced asthmatic lung tissue, we observed a marked infiltration of inflammatory cells into the perivascular and the peribronchiolar regions (Figure 6A-E), and airway mucus hypersecretion (Figure 6F-J) compared with the normal tissue. Cell infiltration and mucus hypersecretion in lungs of Bt-sensitized were attenuated by treatment with AcE when compared with the level seen in Bt-sensitized mice, as shown in Figure 6.

\section{Effect of treatment with AcE or Qt on cytokine levels in BAL fluid}

To determine whether AcE or Qt influenced the generation of a Th2-type immune response, cytokine concentrations in BAL fluid (IL-4, IL-5 and IL-13) were measured by ELISA 24 hours after the last challenge. As shown in Figure 7, Bt-sensitized animals had significantly higher IL-4 ( $p<0.01)$, IL-5 ( $\mathrm{p}<0.01)$ and IL-13 ( $<<0.05)$ levels in the BAL fluid than control mice. In Bt-sensitized mice the treatment with AcE or Qt significantly decreased IL-4 and IL-5 levels $(\mathrm{p}<0.05)$ when compared with the levels seen in the
Bt-sensitized group. The oral treatment with AcE did not affect the levels of IL-13 in the BAL of Bt-sensitized mice.

\section{Effect of treatment with AcE or Qt on serum levels of Bt-specific IgE antibodies}

The cross-linking of allergen-specific IgE on the surface of mast cells upon allergen challenge is relevant to the initiation of the early asthmatic reaction. The serum levels of Bt-specific IgE were measured 24 hours after the last challenge. We observed that sensitization and challenge with Bt resulted in increased serum levels of Bt-specific IgE when compared with non-sensitized animals $(p<0.001)$. The treatment of sensitized mice with AcE or Qt did not reduce significantly Bt-specific IgE (Figure 8).

\section{Discussion}

The chronic inflammatory response to allergens on allergic asthma is characterized by eosinophilia, airway hyperresponsiveness (AHR) and increased mucus production. The actions of inflammatory cells in airways are tightly regulated by a network of Th2 cytokines, such as IL (interleukin)-4, IL-5, and IL-13 [34]. The present study was conducted using a murine model of allergic airway disease induced by Blomia tropicalis mite that was previously characterized by our research group [29]. Previous studies show that once Bt sensitization induced cells infiltration to the lungs, increased EPO activity and high amounts of Bt-specific IgE were obsrved. All these were associated to a Th2-type cytokine profile (with the production of IL-5, IL-13 and IL-4), which is important for the development and maintenance of the Th2 response characteristic of asthma $[29,15]$. The resolution of inflammation is fundamental to the return of normal physiological parameters. In this study we observed that Allium cepa L. and quercetin were associated to anti-inflammatory and bronchodilator activities in an airway inflammation murine model of asthma. As previously described [29], the total BAL cell numbers were increased in Bt-sensitized mice.

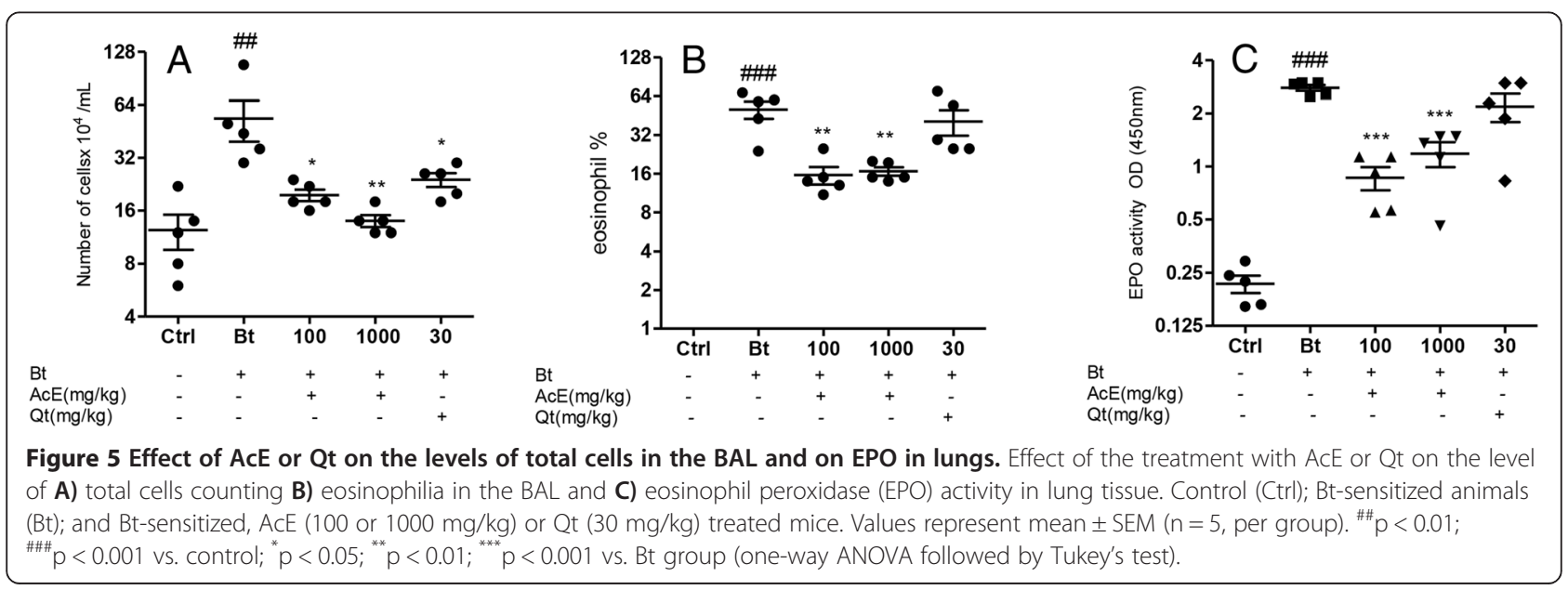




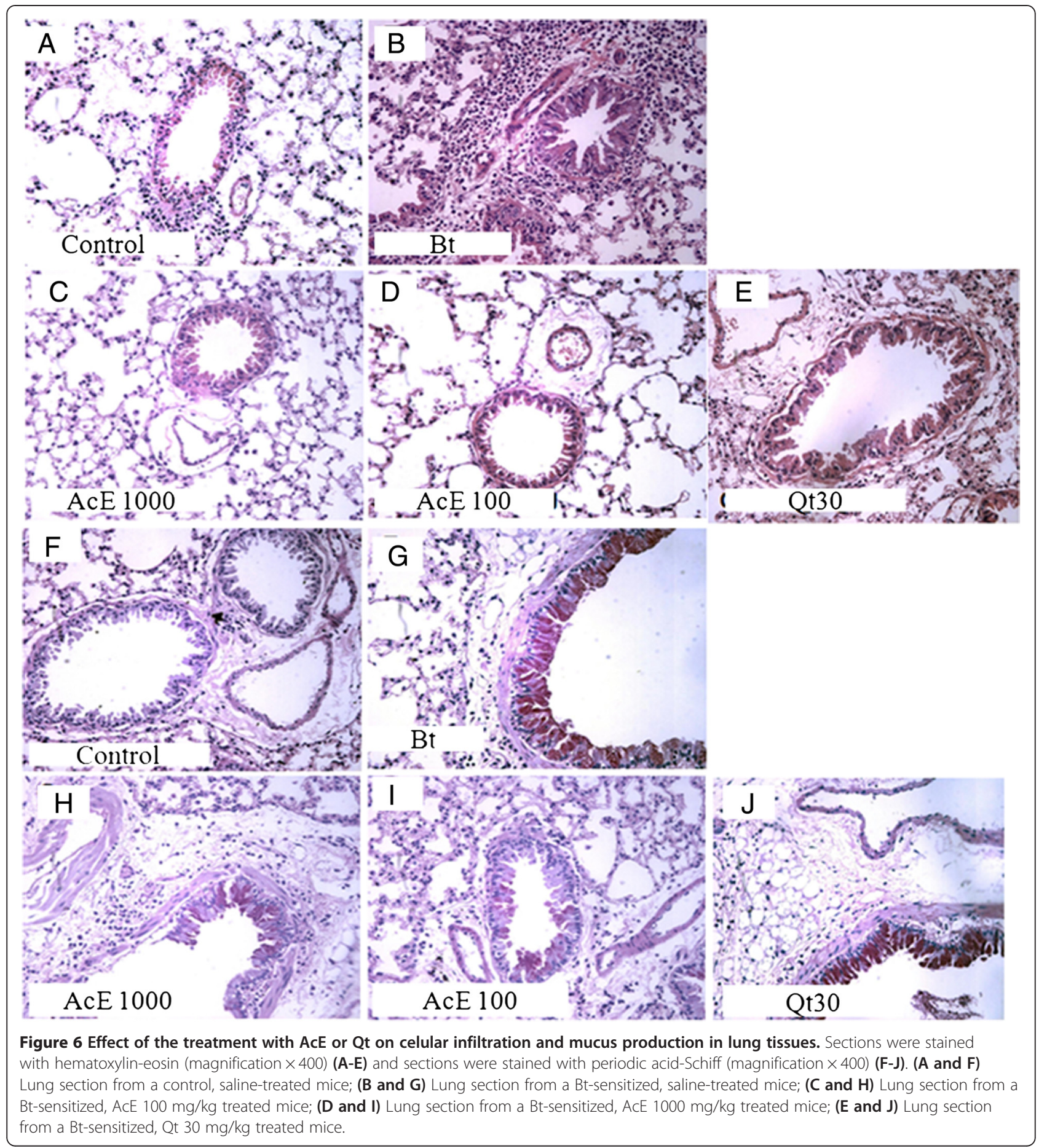

Additionally, there was a statistically significant decrease in total cell numbers in the groups of Bt-sensitized animals treated with $\mathrm{AcE}_{10}, \mathrm{AcE}_{1000}$, or $\mathrm{Qt}_{30}$. Drugs that modulate the recruitment of eosinophils and their activation may be important in reducing lung inflammation in asthma $[35,29,36]$. AcE and Qt when administered to allergic mice induce a decrease in total cellularity in BAL, a parameter required to suppress eosinophil degranulation.
Despite the fact that $\mathrm{Qt}_{30}$ did not significantly modulate $\mathrm{EPO}$ in the lung, the Bt-sensitized mice treated with $\mathrm{AcE}_{100}$ or $\mathrm{AcE}_{1000}$ had significantly lower EPO levels than untreated Bt-sensitized control mice, suggesting that a substance other than Qt is mediating this effect in AcE.

Previous studies in humans have shown that the addition of anti-IL-5 monoclonal antibody on asthma therapy significantly accelerated apoptosis of eosinophils, thereby 


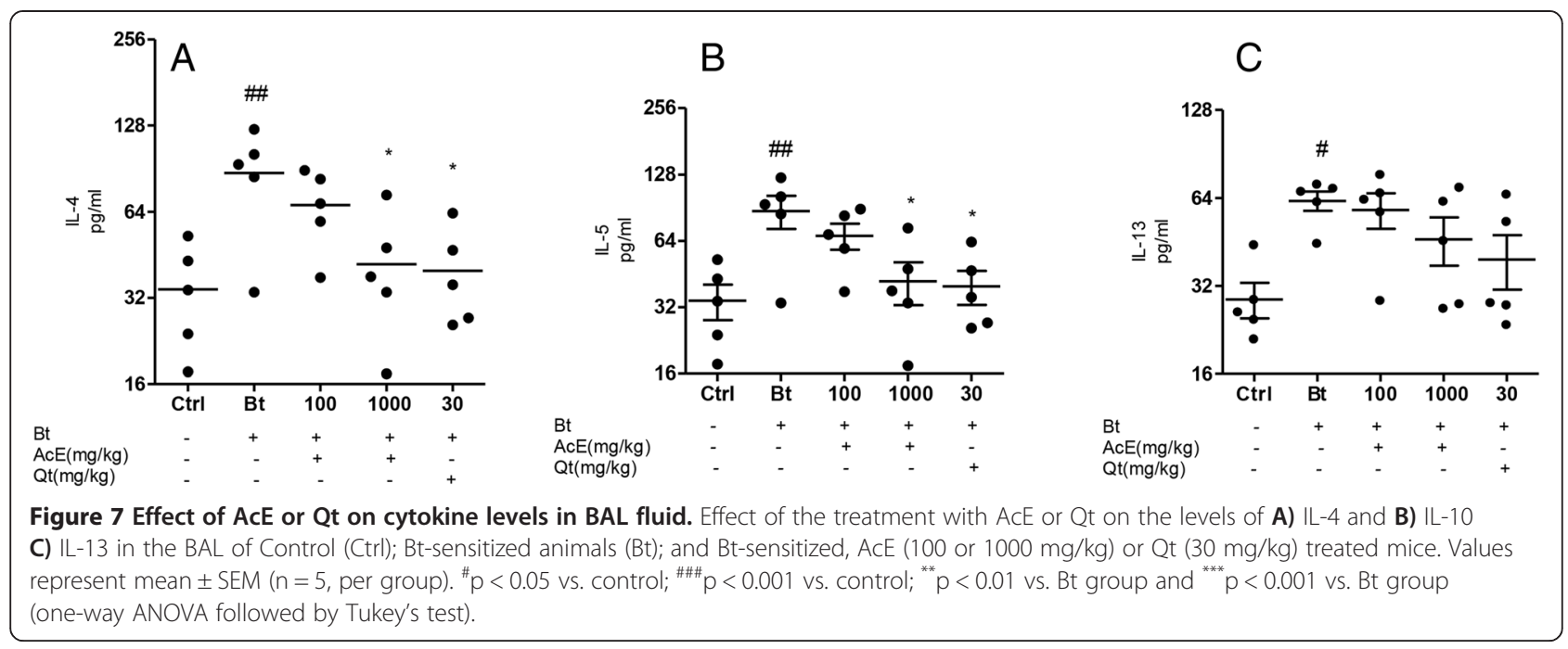

decreasing pulmonary eosinophilia [37]. In this study, we could observe a significant reduction of IL-5, accompanied by a significant decrease in eosinophil peroxidase in the lungs of sensitized mice treated with Bt and AcE.

AcE and Qt had a statistically significant inhibitory effect on IL-4 and IL-5 levels in the BAL fluid of mice treated with $\mathrm{AcE}_{100}$ and $\mathrm{Qt}_{30}$. Despite the modulation of IL-13 in vitro, a similar effect could not be observed in vivo. AcE and Qt suppressed the secretion of IL-4, IL-5 and IL-13 by spleen cells stimulated with PWM. This fact reinforces the importance of in vivo studies to elucidate the mechanisms involved in drug activities.

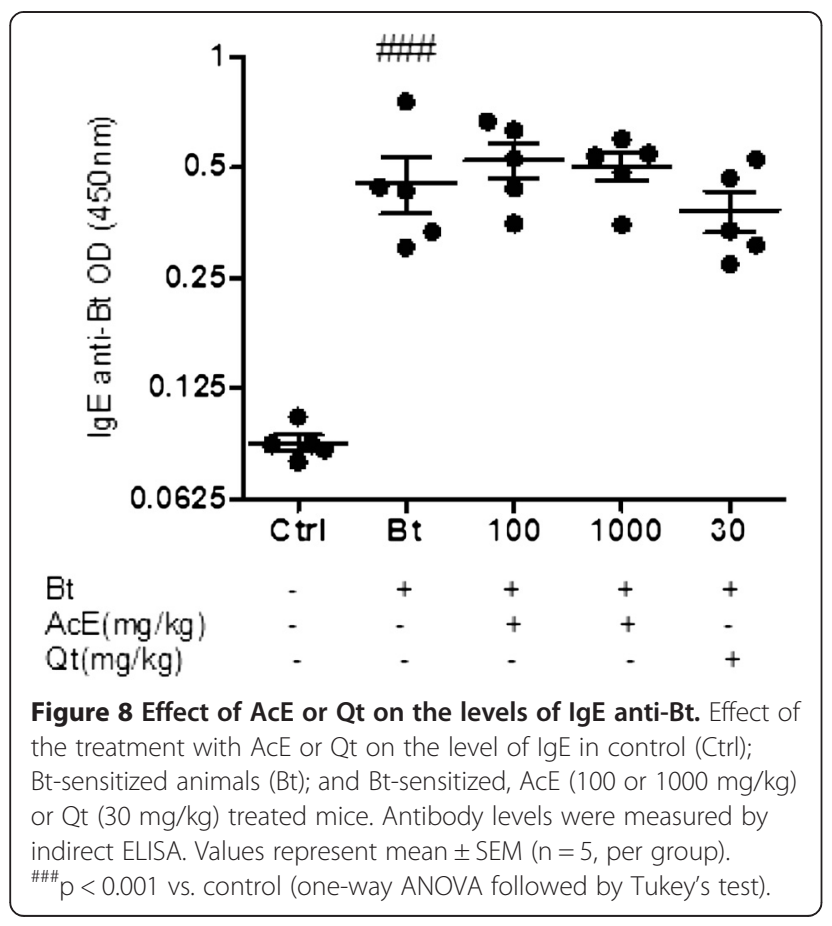

IL-4 along with IL-5 modulates eosinophil activation to stimulate B cells, IgE production, and mast cell degranulation [38] and their reduction, has been shown in this study, could be involved in the modulation of symptoms of allergic disease.

IL-13 also plays important role in allergic asthma $[33,34]$, such as eosinophilic lung infiltration and mucus hypersecretion $[39,40]$, which could be observed in our allergic mice. As there was no significant modulation of IL -13 by the tested drugs, we believe that in this work, as well as in other prior work, mucus is strongly connected to increased levels of IL-13 on asthmatic mice [40]. Nevertheless, $\mathrm{AcE}\left(\mathrm{AcE}_{100}\right)$ was able to decrease the amount of mucus in the lungs of treated and Btsensitized mice. This effect was not observed with $\mathrm{Qt}_{30}$.

Regarding IgE levels, no reduction on antibody titers were observed. These results may be related to the lack of a modulating effect on IL-13, which in addition to IL-4, is an important regulator of IgE production. Another hypothesis to explain the absence of effect on IgE levels is related to the short duration of our acute model, which may not be suitable for evaluating humoral responses, considering the necessary time for the variation in certain cytokine levels to reflect on serum antibody concentrations.

The interaction between the allergen and IgE present on mast cells plays a critical role in allergic inflammation. IgE cross-linking on mast cells leads to the release of histamine, prostaglandin (PG) D2 and leukotrienes, which results in smooth muscle contraction, mucous secretion and vasodilatation $[41,42]$. In previous studies $[25,27,28]$, the therapeutic potential of flavonoids in isolated trachea was investigated. In this study it was observed that both AcE and Qt exerted a relaxing activity on the smooth muscle of isolated murine trachea precontracted with Cch. Additionally, our study supports the findings that interleukin- 13 has been implicated as 
a key cytokine in smooth muscle hyperreactivity on asthma, since we demonstrated an increased contractility in response to Cch in airway smooth muscle induced by IL-13 [33]. Significant changes in Emax were observed, indicating that IL-13 seemed to increase smooth muscle contractility and cause hyperreactivity at the level of contractions. However the bronchodilatory potential of AcE or Qt is not selective for IL-13-induced hyperactivity pathway, as there was no difference between their effect on hyperreactive smooth muscle (IL-13- sensitized) and their effect on normal smooth muscle.

This study corroborates other previous studies on the anti-inflammatory and antiallergic properties of Allium cepa L. and quercetin [16-19,25], which might be linked to the ability of AcE an quercetin in down-modulate inflammatory processes through different signaling pathways such as NF-kB [43-45]. On the other hand, some authors discuss allergic reaction to onion. In such previous studies regarding onion hypersensitivity, authors reported patients producing IgE as well as cell-mediated mechanisms against plant lipid transfer proteins (LTPs) [46]. These are a group of highly-conserved proteins found in higher plant tissues [47]. The hypersensitivity to onion has been described as a cause of asthma induced by handling of onions. However, few publications in the literature report allergic reactions due to onion ingestion despite its wide use [48]. No toxic effect was found in animals exposed to AcE in the present study (data not shown).

AcE displayed a greater efficacy when compared to Qt, as it was able to regulate a greater amount of the parameters evaluated. This research corroborates with previous studies of natural products, which state that better biological responses can be achieved by the additive or synergistic effects of different compounds from an extract [49]. However, further studies are required in order to elucidate the cellular and molecular mechanisms by which AcE performs its action and to determine what substances are present in AcE in addition to quercetin, that contribute to the observed biological responses.

\section{Conclusions}

The results obtained in this work provide the first evidence that Allium cepa L. may have an anti-allergic effect more intense than Qt, and may be a future target for new molecules to treat allergic asthma. Our work may also validate and explain the long-held traditional use of this species by folk Brazilian medicine to treat asthma. This work also opens new perspectives in the context of elucidating the cellular and molecular mechanisms involved in the mechanism of action of Allium cepa L. as a way to enable clinical trials to evaluate its efficacy in humans.

\section{Competing interests}

The authors declare that they have no competing interests.

\section{Authors' contributions}

TTO- Collaboration in vitro and vivo experiments, statistical analysis, interpretation of data, draft of the manuscript and revising. KMC-Collaboration in in vitro and in vivo experiments, statistical analysis, interpretation of data, draft of the manuscript. ANCL- Collaboration in in vivo experiments and revising the manuscript. TCBC-Collaboration in in vitro experiments and revising the manuscript. ESV- study design and AcE supervised the extract production. ICARM and EAF- standardization of the extract in terms of quercetin concentration by high performance liquid chromatography (HPLC). EJO- Study design, standardization of the extract in terms of quercetin concentration by high performance liquid chromatography (HPLC), draft of the manuscript and final review. DFSAV-Collaboration in in vitro experiments, draft of the manuscript and revising the manuscript. LPC- study design, draft of the manuscript and revising the manuscript. NMAN- study design, draft the manuscript and revising the manuscript. CAF- study design, interpretation of data, draft the manuscript and revising the manuscript. All authors read and approved the final manuscript.

\section{Acknowledgments}

The authors want to thank the Brazilian agencies FAPESB, CNPq and CAPES for financial support.

\section{Author details}

${ }^{1}$ Instituto de Ciências da Saúde, Universidade Federal da Bahia, Salvador, Bahia, Brazil. 'Faculdade de Farmácia, Universidade Federal da Bahia, Salvador, Bahia, Brazil. ${ }^{3}$ Centro de Biotecnologia, Universidade Federal da Paraíba, João Pessoa, Paraíba, Brazil. ${ }^{4}$ Centro de Pesquisas Gonçalo Moniz, Fundação Oswaldo Cruz, Salvador, Bahia, Brazil.

Received: 19 August 2014 Accepted: 23 January 2015

Published online: 21 February 2015

\section{References}

1. Hogg JC. Pathology of asthma. J Allergy Clin Immunol. 1993;92:1-5.

2. Holgate S, Smith N, Massanari M, Jimenez P. Effects of omalizumab on markers of inflammation in patients with allergic asthma. Allergy. 2009;64(12):1728-36.

3. Lougheed MD, Olajos-Clow JG. Asthma care pathways in the emergency department. Curr Opin Allergy Clin Immunol. 2010;10(3):181-7.

4. Deckers J, Branco Madeira F, Hammad H. Innate immune cells in asthma. Trends Immunol. 2013;34(11):540-7.

5. Illi S, Depner M, Genuneit J, Horak E, Loss G, Strunz-Lehner C, et al. Protection from childhood asthma and allergy in Alpine farm environments-the GABRIEL Advanced Studies. J Allergy Clin Immunol. 2012;129:1470-7.

6. Barnes PJ. Theophylline: new perspectives for an old drug. Am J Respir Crit Care Med. 2003;167(6):813-8.

7. Nauta AJ, Engels F, Knippels LM, Garssen J, Nijkamp FP, Redegeld FA. Mechanisms of allergy and asthma. Eur J Pharmacol. 2008;585(2-3):354-60.

8. Lee SI. Prevalence of childhood asthma in Korea: international study of asthma and allergies in childhood. Allergy Asthma Immunol Res. 2010;2(2):61-4.

9. Zar HJ, Levin ME. Challenges in treating pediatric asthma in developing countries. Paediatr Drugs. 2012;14:353-9.

10. Kew KM, Karner C, Mindus SM, Ferrara G. Combination formoterol and budesonide as maintenance and reliever therapy versus combination inhaler maintenance for chronic asthma in adults and children. Cochrane Database Syst Rev. 2013;12:CD009019.

11. Hashimoto S, Bel EH. Current treatment of severe asthma. Clin Exp Allergy. 2012;42(5):693-705.

12. Busse W. Asthma diagnosis and treatment: filling in the information gaps. J Allergy Clin Immunol. 2011;128:740-50.

13. Martinez FD, Vercelli D. Asthma. Lancet. 2013;382(9901):1360-72.

14. Mullane K. The increasing challenge of discovering asthma drugs. Biochem Pharmacol. 2011;82(6):586-99.

15. Costa RS, Brasil TC, Santos CJ, Santos DB, Barreto ML, Alcântara-Neves NM, et al. Natural products used for asthma treatment in children living in Salvador-BA, Brazil. Rev Bras Farmacogn. 2010;20:594-9.

16. Dorsch W, Wagner H, Bayer T, Fessler B, Hein G, Ring J, et al. Anti-asthmatic effects of onions. Alk(en)ylsulfinothioic acid alk(en)yl-esters inhibit histamine release, leukotriene and thromboxane biosynthesis in vitro and counteract PAF and allergen-induced bronchial obstruction in vivo. Biochem Pharmacol. 1988;1;37(23):4479-86. 
17. Kaiser P, Youssouf MS, Tasduq SA, Singh S, Sharma SC, Singh GD, et al. Anti-allergic effects of herbal product from Allium cepa (bulb). J Med Food. 2009;12(2):374-82.

18. Rogerio AP, Kanashiro A, Fontanari C, da Silva EV, Lucisano-Valim YM, Soares EG, et al. Anti-inflammatory activity of quercetin and isoquercitrin in experimental murine allergic asthma. Inflamm Res. 2007;56(10):402-8.

19. Park HJ, Lee CM, Jung ID, Lee JS, Jeong YI, Chang JH, et al. Quercetin regulates Th1/Th2 balance in a murine model of asthma. Int Immunopharmacol. 2009;9(3):261-7.

20. Elberry AA, Mufti S, Al-Maghrabi J, Abdel Sattar E, Ghareib SA, Mosli HA, et al. Immunomodulatory effect of red onion (Allium cepa Linn) scale extract on experimentally induced atypical prostatic hyperplasia in Wistar rats. Mediators Inflamm. 2014:2014:640746

21. Guo C, Hou GQ, Li XD, Xia X, Liu DX, Huang DY, et al. Quercetin triggers apoptosis of lipopolysaccharide (LPS)- induced osteoclast and inhibits bone resorption in RAW 264.7 cells. Cell Physiol Biochem. 2012;30(1):123-36.

22. Kubec R, Cody RB, Dane AJ, Musah RA, Schraml J, Vattekkatte A, et al. Applications of direct analysis in real time-mass spectrometry (DART-MS) in Allium chemistry. (Z)-butanethial S-oxide and 1-butenyl thiosulfinates and their S-(E)-1-butenylcysteine S-oxide precursor from Allium siculum. J Agric Food Chem. 2010;58(2):121-8.

23. Løkke MM, Edelenbos M, Larsen E, Feilberg A. Investigation of volatiles emitted from freshly cut onions (Allium cepa L.) by real time proton-transfer reaction-mass spectrometry (PTR-MS. Sensors (Basel). 2012;12(12):16060-76.

24. Colina-Coca C, González-Peña D, Vega E, de Ancos B, Sánchez-Moreno C. Novel approach for the determination of volatile compounds in processed onion by headspace gas chromatography-mass spectrometry (HS GC-MS). Talanta. 2013:103:137-44

25. Joskova M, Franova S, Sadlonova V. Acute bronchodilator effect of quercetin in experimental allergic asthma. Bratisl Lek Listy. 2011;112(1):9-12.

26. Fernández-Caldas E, Puerta L, Caraballo L. Mites and allergy. Chem Immunol Allergy. 2014;100:234-42.

27. Capasso R, Aviello G, Romano B, Atorino G, Pagano E, Borrelli F. Inhibitory effect of quercetin on rat trachea contractility in vitro. J Pharm Pharmacol. 2009;61(1):115-9.

28. Fernandez J, Reyes $R$, Ponce $H$, Oropeza M, Vancalsteren MR, Jankowski C, et al. Isoquercitrin from Argemone platyceras inhibits carbachol and leukotriene D4-induced contraction in quinea-pig airways. Eur J Pharmacol. 2005;522(1-3):108-15.

29. Baqueiro T, Russo M, Silva VM, Meirelles T, Oliveira PR, Gomes E, et al. Respiratory allergy to Blomia tropicalis: immune response in four syngeneic mouse strains and assessment of a low allergen-dose, short-term experimental model. Respir Res. 2010;1:11:51.

30. Ly TN, Hazama C, Shimoyamada M, Ando H, Kato K, Yamauchi R. Antioxidative compounds from the outer scales of onion. J Agric Food Chem. 2005;53(21):8183-9.

31. Lee J, Mitchell AE. Quercetin and isorhamnetin glycosides in onion (Allium cepa L.): varietal comparison, physical distribution, coproduct evaluation, and long-term storage stability. J Agric Food Chem. 2011;59(3):857-63.

32. Bezerra-Santos CR, Balestiari FM, Rossi-Bergmann B, Peçanha LM, Piuvezam MR. Cissampelos sympodialis Eichl. (Menispermaceae): oral treatment decreases lgE levels and induces a Th1-skewed cytokine production in ovalbumin-sensitized mice. J Ethnopharmaco. 2004:95(2-3):191-7.

33. Farghaly HS, Blagbrough IS, Medina-Tato DA, Watson ML. Interleukin13 increases contractility of murine tracheal smooth muscle by a phosphoinositide 3-kinase p110 delta-dependent mechanism. Mol Pharmacol. 2008;73(5):1530-7.

34. Walter DM, McIntire JJ, Berry G, McKenzie AN, Donaldson DD, DeKruyff RH, et al. Critical role for IL-13 in the development of allergen-induced airway hyperreactivity. J Immunol. 2001;167(8):4668-75.

35. Baatjes AJ, Sehmi R, Saito H, Cyr MM, Dorman SC, Inman MD, et al. Anti-allergic therapies: effects on eosinophil progenitors. Pharmacol Ther. 2002;95(1):63-72.

36. Cerqueira-Lima AT, Alcântara-Neves NM, de-Carvalho LC, Costa RS, Barbosa-Filho JM, Piuvezam M, et al. Effects of Cissampelos sympodialis Eichl. and its alkaloid, warifteine, in an experimental model of respiratory allergy to Blomia tropicalis. Curr Drug Targets. 2010;11(11):1458-67.

37. Simon HU, Yousefi S, Schranz C, Schapowal A, Bachert C, Blaser K. Direct demonstration of delayed eosinophil apoptosis as a mechanism causing tissue eosinophilia. J Immunol. 1997;158(8):3902-8.

38. Galli SJ, Tsai M. IgE and mast cells in allergic disease. Nat Med. 2012;18(5):693-704

39. Wynn TA. IL-13 effector functions. Annu Rev Immunol. 2013;21:425-56.
40. Kibe A, Inoue H, Fukuyama S, Machida K, Matsumoto K, Koto H, et al. Differential regulation by glucocorticoid of interleukin-13-induced eosinophilia, hyperresponsiveness, and goblet cell hyperplasia in mouse airways. Am J Respir Crit Care Med. 2003;167(1):50-6.

41. Bateman ED, Hurd SS, Barnes PJ, Bousquet J, Drazen JM, FitzGerald M, et al Global strategy for asthma management and prevention: GINA executive summary. Eur Respir J. 2008;31(1):143-78.

42. Hamid Q, Tulic M. Immunobiology of asthma. Annu Rev Physiol. 2009;71:489-507.

43. Yamaguchi M, Weitzmann MN. Quercetin, a potent suppressor of NF-KB and Smad activation in osteoblasts. Int J Mol Med. 2011;28(4):521-5.

44. Tang CH, Huang TH, Chang CS, Fu WM, Yang RS. Water solution of onion crude powder inhibits RANKL-induced osteoclastogenesis through ERK, p38 and NF-kappab pathways. Osteoporos Int. 2009;20(1):93-103.

45. Wattel A, Kamel S, Prouillet C, Petit JP, Lorget F, Offord E, et al. Flavonoid quercetin decreases osteoclastic differentiation induced by RANKL via a mechanism involving NF kappa B and AP-1. J Cell Biochem. 2004;92(2):285-95.

46. Valdivieso R, Subiza J, Varela-Losada S, Subiza JL, Narganes MJ, MartinezCocera $C$, et al. Bronchial asthma, rhinoconjunctivitis, and contact dermatitis caused by onion. J Allergy Clin Immunol. 1994;94(5):928-30.

47. Asero R, Mistrello G, Roncarolo D, Amato S. Relationship between peach lipid transfer protein specific lgE levels and hypersensitivity to non-Roseaceae vegetable foods in patients allergic to lipid transfer protein. Ann Allergy Asthma Immunol. 2004;92(2):268-72.

48. Enrique E, Malek T, De Mateo JA, Castelló J, Lombardero M, Barber D, et al. Involvement of lipid transfer protein in onion allergy. Ann Allergy Asthma Immunol. 2007:98(2):202.

49. Jaki BU, Franzblau SG, Chadwick LR, Lankin DC, Zhang F, Wang Y, et al. Purity-activity relationships of natural products: the case of anti-TB active ursolic acid. J Nat Prod. 2008;71(10):1742-8.

\section{Submit your next manuscript to BioMed Central and take full advantage of:}

- Convenient online submission

- Thorough peer review

- No space constraints or color figure charges

- Immediate publication on acceptance

- Inclusion in PubMed, CAS, Scopus and Google Scholar

- Research which is freely available for redistribution 